\title{
Explosion of lithium-thionyl-chloride battery due to presence of lithium nitride
}

\author{
Hennesø, E.; Hedlund, Frank Huess
}

Published in:

Journal of Failure Analysis and Prevention

Link to article, DOI:

10.1007/s11668-015-0004-y

Publication date:

2015

Document Version

Early version, also known as pre-print

Link back to DTU Orbit

Citation $(A P A)$ :

Hennesø, E., \& Hedlund, F. H. (2015). Explosion of lithium-thionyl-chloride battery due to presence of lithium nitride. Journal of Failure Analysis and Prevention, 15(5), 600-603. https://doi.org/10.1007/s11668-015-0004-y

\section{General rights}

Copyright and moral rights for the publications made accessible in the public portal are retained by the authors and/or other copyright owners and it is a condition of accessing publications that users recognise and abide by the legal requirements associated with these rights.

- Users may download and print one copy of any publication from the public portal for the purpose of private study or research.

- You may not further distribute the material or use it for any profit-making activity or commercial gain

- You may freely distribute the URL identifying the publication in the public portal

If you believe that this document breaches copyright please contact us providing details, and we will remove access to the work immediately and investigate your claim. 
This article appeared in Journal of Failure Analysis and Prevention, ISSN 1547-7029

http://dx.doi.org/10.1007/s11668-015-0004-y

\section{Explosion of lithium-thionyl- chloride battery due to presence of lithium nitride}




\section{Erik HENNESØ}

M.Sc. Chem. Eng., PhD (retired)

Blegdammen 28, 4600 Køge, Denmark. E-mail erik@hennesoe.com

Frank Huess HEDLUND ${ }^{\mathrm{a}}$,

COWI; Parallelvej 2, DK-2800 Kongens Lyngby, Denmark. Telephone +45

5640 1330. Fax +45 5640 9999. E-mail: fhhe@,cowi.dk ${ }^{\mathrm{b}}$

Technical University of Denmark, (DTU/Compute) DK-2800 Kongens

Lyngby, Denmark. E-mail fhuhe@dtu.dk

${ }^{a}$ corresponding author

${ }^{\mathrm{b}}$ corresponding address

\section{Abstract}

An explosion of a lithium-thionyl-chloride ( $\mathrm{Li}$-SOCl 2 ) battery during production (assembly) lead to serious worker injury. The accident cell batch had been in a dry-air intermediate storage room for months before being readied with thionyl chloride electrolyte. Metallic lithium can react with atmospheric nitrogen to produce lithium nitride. Nodules of lithium nitride $\left(\mathrm{Li}_{3} \mathrm{~N}\right)$ were found to be present on the lithium foil in other cells of the accident batch. The investigation attributed the explosion to the formation of porous lithium nitride during intermediate storage and a violent exothermal decomposition with the $\mathrm{SOCl}_{2}-\mathrm{LiAlCl}_{4}$ electrolyte triggered by welding. The literature is silent on hazards of explosion of $\mathrm{Li}_{-} \mathrm{SOCl}_{2}$ cells associated with the presence of lithium nitride. The silence is intriguing. Possible causes may be that such explosions are very rare, that explosions go unpublished precisely as this case initially did, or a combination of the two. 


\section{Table of Contents}

1 Introduction 3

1.1 Lithium batteries 3

1.2 Battery details 3

1.3 Explosion 4

$2 \quad$ Investigation $\quad 5$

2.1 Examination of accident production batch 5

2.2 Likely explosion mechanism 5

2.3 No production irregularities identified 6

2.4 The welding process 6

2.5 Heating and short circuit tests 6

2.6 Crush tests 6

3 Discussion $\quad \mathbf{8}$

3.1 Experimental evidence for an exothermic reaction

3.2 Porous $\mathrm{Li}_{3} \mathrm{~N}$ hypothesis 8

3.3 Tetrasulfur tetranitride trigger hypothesis 9

3.4 Literature silent on lithium nitride explosion hazards 9

4 Conclusion 10

$\begin{array}{lll}5 & \text { Acknowledgements } & 11\end{array}$

6 References 12 


\section{Introduction}

\subsection{Lithium batteries}

Primary lithium batteries present a range of technical advantages such as high energy density, long shelf life, excellent discharge characteristics and functional tolerance for temperature extremes. The lithium thionyl chloride $\left(\mathrm{Li}-\mathrm{SOCl}_{2}\right)$ system is the most important system with a fluid cathodic substance and offers an outstanding practical energy density and specific energy at especially high loadability [1], [2].

The Li-SOCl 2 system also presents safety concerns however. The chemical reactivity, corrosiveness and toxic nature of the materials of construction have occasionally led to accidents at the manufacturing facility [3]. In case of battery abuse (e.g. short circuit) users may experience problems with thermal runaway, venting of toxic gasses or explosion, which in extreme cases have led to accidents with serious injury or fatal outcome [4], [5], [6].

The accident battery was a so-called bobbin low rate construction where a foil of lithium metal is pressed onto the inside wall of the steel container. In this battery construction, the relatively low lithium surface area limits the rate of excess heat generated and simplifies thermal management (overheat protection) issues. The type is considered safer than so-called high rate cells, which have spirally wound lithium foil electrodes and hence a larger surface area.

\subsection{Battery details}

The accident cell was a R14 stainless steel (type 304) container with metallic lithium foil as anode, thionyl chloride as cathode, compressed powdered carbon and nickel mesh as current collector and a glass fibre nonwoven separator (Figure 1). The lithium foil thickness was $1.4 \mathrm{~mm}$. The electrolyte was prepared adding $\mathrm{AlCl}_{3}$ and $\mathrm{LiCl}$ salts to anhydrous $\mathrm{SOCl}_{2}$ to yield a solution of $1.73 \mathrm{M} \mathrm{LiAlCl}_{4}$, about $300 \mathrm{~g} / \mathrm{l}$. Henceforth, the article will refer to this solution as the thionyl chloride electrolyte, or simply the electrolyte.

Production took place in two steps. After assembly of the major components, cells were kept for some time in a dry-air $(<1 \%$ relative humidity) room for intermediate storage. Cells were then readied with thionyl chloride electrolyte, sealed, and completed with electrode terminals etc. 


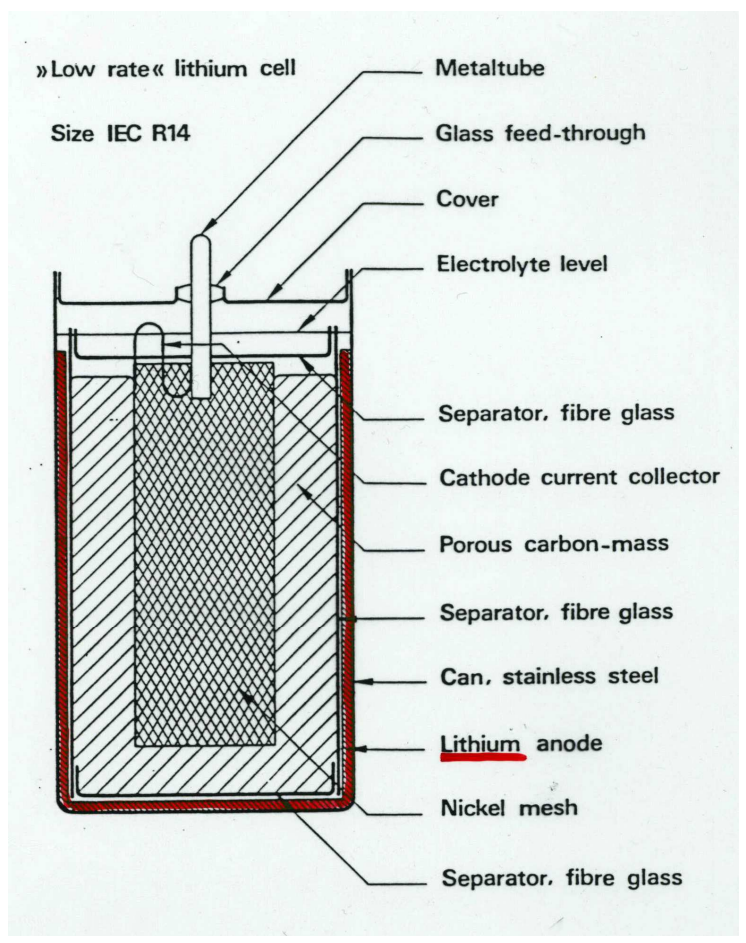

Figure $1 \quad$ Schematic construction of accident R14 cell

\subsection{Explosion}

The anode terminal, a nickel strip, was welded to the side of the steel container. The point of attachment was near the upper edge of the metallic lithium foil inside the container. Eye protection was worn because of potential welding sparks. The manual work operation was otherwise considered unhazardous.

At the day of the accident, a cell suddenly exploded during welding. The explosion was so forceful that the assembly worker lost a finger. 


\section{Investigation}

\subsection{Examination of accident production batch}

The accident cell was part of a production batch that had been kept in dry-air intermediate storage for about 11 months, an unusually long time.

Examination of other cells of the accident production batch revealed the presence of nodules of crystals on the lithium foil ranging in colour from black to brown-red.

The nodules were cone shaped and appeared to have originated from a small contact area at the glass fibre separator and expanded as they grew into and sometimes through the lithium foil. In cases with full penetration of the foil, the nodule area could reach $0.5-2.5 \mathrm{~cm}^{2}$. Auger electron spectroscopy analysis of nodule material identified a mixture of lithium oxide $\left(\mathrm{Li}_{2} \mathrm{O}\right)$ and lithium nitride $\left(\mathrm{Li}_{3} \mathrm{~N}\right)$ or lithium oxynitride (LiNO). Nodule material extracted from two batteries weighed $175 \mathrm{mg}$ and $415 \mathrm{mg}$, respectively.

Nodule material wetted with thionyl chloride electrolyte was clearly unstable and could be brought to explode when scratched with a pair of tweezers. The explosion of $20 \mathrm{mg}$ of nodule material gave a discernible pressure wave in a 40 litres glove box. Explosion could also be triggered when heated to $400{ }^{\circ} \mathrm{C}$ with a soldering iron. Unwetted nodule material was generally stable. Because of these findings, the investigation focussed on the reactivity of the wetted nodule material.

\subsection{Likely explosion mechanism}

Metallic lithium reacts slowly with atmospheric nitrogen to produce lithium nitride. The accident investigation committee concluded that unusually large amounts of $\mathrm{Li}_{3} \mathrm{~N}$ had formed during the extended intermediate storage. The working hypothesis was that lithium nitride wetted with electrolyte was unstable and that welding had triggered an explosion.

In an attempt to reproduce the explosion, the welding procedure was repeated on cells from the same production batch and electrolyte batch as the accident cell ("sister cells"). Quite surprisingly, welding on 2,579 "sister cells" failed to produce a single explosion however. 
Nonetheless, the accident investigation committee eventually concluded that $\mathrm{Li}_{3} \mathrm{~N}$ was the most plausible candidate responsible for the explosion. As described below, no other more plausible mechanism could be identified.

\subsection{No production irregularities identified}

All production journals were examined and no irregularities were identified. Infrared spectroscopy analysis of the electrolyte of two accident production batch cells ("sister cells") showed slightly elevated water contents but still within the normal range. The concentrations of sulphur dioxide $\left(\mathrm{SO}_{2}\right)$ and dichlorine monoxide $\left(\mathrm{Cl}_{2} \mathrm{O}\right)$ were minimal. No contamination or other anomalies were identified. The electrolyte was normal.

\subsection{The welding process}

The plasma welding equipment was examined and found without fault. The ability of a stray welding current to affect the electrochemical system was considered unlikely. The welding energy was low, typically about $50 \mathrm{~J}$ and the electric current would flow mainly in the steel container, not in the metallic lithium foil, in part because of the narrow distance between the welding electrodes.

Heat impact was considered possible however. Calculations showed that during welding, the temperature on the inside of an empty steel container could reach about $450{ }^{\circ} \mathrm{C}$ for some $10-20$ milliseconds. While the temperature increase would be lower in a filled steel container, it was considered plausible that it could trigger an explosion of unstable nodule material.

\subsection{Heating and short circuit tests}

Two "sister cells" were heated in a silicone oil bath. The first cell showed a weak exothermic reaction at $120-140{ }^{\circ} \mathrm{C}$ and an expected plateau at $180{ }^{\circ} \mathrm{C}$, the melting point of metallic lithium. The cell exploded at $250^{\circ} \mathrm{C}$, like normal reference cells could do. The second cell lost voltage at $250{ }^{\circ} \mathrm{C}$ when the glass feed-through failed and the electrolyte evaporated. The test was terminated at $300{ }^{\circ} \mathrm{C}$ without explosion.

During the normal weld procedure the plasma welding electrodes are not near the positive pole of the cell and a short circuit caused by the welding equipment was considered unlikely. Still, five test were carried out on "sister cells" that were thermally insulated in mineral wool and then short circuited. Maximum recorded temperatures were $145,88,170,175$ and $170{ }^{\circ} \mathrm{C}$. In four cells, the glass feed-through failed. None of the cells exploded.

\subsection{Crush tests}

Crush tests were carried out with a $5.7 \mathrm{~kg}$ iron cylinder dropped from a height of $4 \mathrm{~m}$. "Sister cells" generally exploded upon crushing impact. Reference 
cells taken from other production batches did not explode when subjected to this test. Explosion of reference cells could occasionally be observed at a second crush impact attempt, when the crushed cell had been exposed to moist air for several minutes. 


\section{Discussion}

\subsection{Experimental evidence for an exothermic reaction involving $\mathrm{Li}_{3} \mathrm{~N}$}

Dallek et al. [7] carried out differential scanning calorimetry (DSC) measurements on various components of $\mathrm{Li}-\mathrm{SOC}_{2}$ cells to identify those combinations that react exothermically and might cause batteries to explode. The study reported that $\mathrm{Li}_{3} \mathrm{~N}$ undergoes violent exotherms with $\mathrm{SOCl}_{2}$ at 196 ${ }^{\circ} \mathrm{C}$ and with the $\mathrm{SOCl}_{2}-\mathrm{LiAlCl}_{4}$ system at $132{ }^{\circ} \mathrm{C}$.

Differential thermal analysis (DTA) measurements carried out by the company on $\mathrm{Li}_{3} \mathrm{~N}$ nodule material were unable to reproduce the results reported by Dallek et al. however.

\subsection{Porous $\mathrm{Li}_{3} \mathrm{~N}$ hypothesis}

Upon reaction with atmospheric nitrogen and lithium metal, crystals of reddish brown lithium nitride are known to extend into the interior of the metal over time [8].

The accident investigation committee theorized that because the specific density of lithium nitride (1.38) is considerably larger than that of lithium metal (0.53) the porosity of the formed nodules of nitride crystals would allow diffusion of nitrogen to freshly exposed metal, thereby sustaining continued reaction and growth of the nodule. The porosity would also provide a large surface area for the reaction between $\mathrm{Li}_{3} \mathrm{~N}$ and $\mathrm{SOCl}_{2}$.

Indeed, we argue that a large contact area is a precondition for an explosive reaction to take place between a solid and a liquid substance.

Porosity issues might also explain why verification trials carried out by the company could not reproduce the exotherms reported by Dallek et al. [7]. They had used commercially available finely divided $\mathrm{Li}_{3} \mathrm{~N}$ powder, which may have had a larger surface area than the $\mathrm{Li}_{3} \mathrm{~N}$ nodule material extracted from the lithium foil of "sister cells". 


\subsection{Tetrasulfur tetranitride trigger hypothesis}

The accident investigation committee briefly theorized that lithium nitride might react with trace amounts of water to produce ammonia and lithium hydroxide. The ammonia might then react with thionyl chloride to produce tetrasulfur tetranitride $\left(\mathrm{S}_{4} \mathrm{~N}_{4}\right)$, which is sensitive to heat and shock and decomposes explosively.

Welding may therefore have triggered explosive decomposition of $\mathrm{S}_{4} \mathrm{~N}_{4}$, which in turn triggered the reaction between $\mathrm{Li}_{3} \mathrm{~N}$ and $\mathrm{SOCl}_{2}$. The formation of shock sensitive $\mathrm{S}_{4} \mathrm{~N}_{4}$ might also explain why cells exploded in the second crush impact test attempt after having been exposed to moist air for several minutes.

The literature on this topic appears extremely sparse. We have only identified a single source [6] on observed shock sensitivity of $\mathrm{Li}-\mathrm{SOCl}_{2}$ cells, and it makes passing mention only.

\subsection{Literature silent on lithium nitride explosion hazards}

Preliminary findings were shared with two other lithium battery makers. For a number of trivial reasons however, the case was never communicated to a wider audience.

We have been unable to identify any literature that mentions the risk of explosion of $\mathrm{Li}-\mathrm{SOCl}_{2}$ cells associated with the formation of lithium nitride. A recent review article [9] and a recent book [10] are silent on the issue. Standard reference works on chemical incompatibilities [11], [12] do not list violent exotherms with $\mathrm{Li}_{3} \mathrm{~N}$ and the $\mathrm{SOCl}_{2}-\mathrm{LiAlCl}_{4}$ system.

The silence is intriguing. Possible causes may be that such explosions are very rare, that explosions go unpublished precisely as this case did, or a combination of the two. 


\section{Conclusion}

Although the exact cause could not be determined with certainty, it was concluded that the most likely cause was that highly porous nodules of lithium nitride wetted with thionyl chloride were present on the inside of the accident battery container near the point of welding. Welding had heated and triggered an exothermal reaction with lithium nitride and the electrolyte.

Practical prevention of recurrence would therefore rely on the ability to keep the formation of unwanted lithium nitride in check. Hence, the maximum duration of dry-air intermediate storage of semi-finished batteries was limited to one week. In addition, the production process was modified so welding of the nickel strip was carried out before the electrolyte filling step. 


\section{$5 \quad$ Acknowledgements}

This article has been produced as voluntary work and has not received any funding. Opinions expressed are those of the authors only, not their employers' or organizations'. 


\section{$6 \quad$ References}

[1] "Kiehne H.A., Battery technology handbook (Vol. 60), CRC Press, 2003".

[2] "Yu G., Zhang X, Wang C., Zhang W., Yang C., Experimental Study on Specific Heat Capacity of Lithium Thionyl Chloride Batteries by a Precise Measurement Method,. Electrochem. Soc., 160 (6) (2013) A985-A989”.

[3] "Konichezky S., Schattner A., Ezri T., Bokenboim P., Geva, D., Thionylchloride-induced lung injury and bronchiolitis obliterans, CHEST Journal, 104(3) (1993) 971-973.".

[4] "Subbarao S., Halpert G., Stein I., Safety considerations of lithium-thionyl chloride cells, Publication 86-16. Jet Propulsion Laboratory, California, USA, 1986".

[5] "Levy S.C., Bro P., Battery hazards and accident prevention, Springer Science \& Business Media, 2013".

[6] "Bowers F.M., Safe, useful lithium batteries for the Navy. NSWC/WOL/TR-77-140, Naval Surface Weapons Center, Md, USA, 1977".

[7] "Dallek, S., James, S. D., \& Kilroy, W. P., Exothermic Reactions among Components of Lithium-Sulfur Dioxide and Lithium-Thionyl Chloride Cells, J. Electrochem. Soc., 128(3) (1981) 508-516.”.

[8] "Wietelmann U., Steinbild M., Lithium and Lithium Compounds, Ullmann's Encyclopedia Of Industrial Chemistry. 2013 Wiley-VCH Verlag GmbH \& Co. KGaA, Weinheim., 2013.”.

[9] "Lisbona D., Snee T., A review of hazards associated with primary lithium and lithium-ion batteries, Process Saf Environ 89 (2011) 434-442".

[10] "Bagotsky V.S., Skundin A.M., Volfkovich Y.M., Electrochemical Power Sources: Batteries, Fuel Cells, and Supercapacitors, 1.ed, John Wiley \& Sons, 2015".

[11] "Urben P.G., Bretherick's Handbook of Reactive Chemical Hazards [Electronic Resource] : an Indexed Guide to Published Data, ScienceDirect (Online service), 2007.".

[12] "Pohanish R.P., Greene S.A., Wiley Guide to Chemical Incompatibilities, John Wiley and Sons, 2009.”. 